Ethiopian Journal of Environmental Studies \& Management 8(2): 141 - 151, 2015.

ISSN:1998-0507

doi: http://dx.doi.org/10.4314/ejesm.v8i2.4

Submitted: November 11, 2014

Accepted: February 10, 2015

\title{
ASSESSING SOCIAL AND ENVIRONMENTAL LINKS IN DEVELOPMENT STRATEGIES FOR CAMEROON: A PROCESS APPROACH TO SUSTAINABILITY
}

*NGOUANA-KENGNE, C.V., ${ }^{1}$ EVOUNA, S.E.M. ${ }^{2}$ AND BITONDO, D. ${ }^{3}$

${ }^{1}$ Centre for Centre Transdisciplinary Studies in Aquaculture, Environment and for Development Support (CTA-AED), PO Box 31616 Yaoundé 13, Cameroon ${ }^{2}$ The World Bank Country Office, Nouvelle Route P O Box 1128, Yaoundé-Cameroon

${ }^{3}$ Faculty of Industrial Engineering, University of Douala, P O Box 2701Douala, Cameroon

\begin{abstract}
The links between the social and environmental pillars are particularly under-developed in scientific literature. This article bridges this knowledge gap by applying a socialenvironmental conceptual framework which consists of a check-list of 33 questions. It used same to review various strategy documents of the Government of Cameroon. These comprised one national strategy document, three sectoral strategy documents and two subsectoral strategy documents. To triangulate and enrich these documents analysis, unstructured interviews with 21 key stakeholders was held. The findings revealed some inconsistencies in participatory processes. Findings also revealed insufficient consideration of benefits sharing from the exploitation of natural resource for local social development. Biopiracy issues were also not well considered in the documents analyzed. Nevertheless, natural and human-induced risk management, environmental awareness, generation and use of data, and commitments to infrastructure planning that concurrently promotes social integration and environmental sustainability simultaneously are well considered in the strategy documents reviewed.
\end{abstract}

Key Words: Development strategies, Cameroon, Check-list, Social and Environmental Links

\section{Introduction}

Many developing countries were able to maintain a stable macro-economic framework up to 2008 by implementing their Poverty Reduction Strategy Papers (IMF, 2010). However, the general pace of growth has been too slow to significantly reduce poverty. For example, in Cameroon during the implementation phase of the Poverty Reduction Strategy Papers (PRSPs), the Gross Domestic Product average growth rate stood at 3.32 per cent between 2003 and 2007 (Republic of Cameroon, 2009). To correct weaknesses

*Corresponding Author: Kengne, V.C.N. 141 identified during successive evaluations of first generation PRSP's implementation, many African countries, have recently launched national strategy of vision that aims at making them emerging countries between 2020-2035. Driscoll and Evans (2005) note that these countries have also revised their PRSPs and prepared a secondgeneration of PRSPs with focus on growth and job creation as the basis of future poverty reduction programs. Cameroon for example has prepared a growth and employment strategy paper (GESP) which is a national strategy. To support the

Email: cyrille_ngouana@yahoo.com 
appropriate planning of subsequent strategies aligned with the GESP, the Government of Cameroon in 2011 published a planning guide (MINEPAT, 2011). Based on this key planning tool, sectoral development strategies, subsectoral development strategies and Priority Action Plans (PAPs) were prepared by different ministries. One can ponder whether the process of preparing these strategies replicates past weaknesses such as the mechanistic breakdown of sustainability into its parts as underscored by Volkery et al. (2004). Much of work was done on the greening of PRSPs and major policy documents in Africa (Bojö et al., 2004; Hugé and Hens, 2009; Hambira, 2009; Alemagi, 2011; Bele et al., 2011) did not place much focus on social and environmental links. The literature indicates the necessity of developing greater linkage between the social and environmental pillars (Murphy, 2012; Cuthill, 2009; Gough et al., 2008; Littig and Griessler, 2005). The central issue is not to establish how social pillar affects environmental pillar (Harms, 1999). It is how social and environmental considerations simultaneously come together at the moment of choice, and how the resulting options/directions lead to sustainability. This paper seeks to understand and evaluate the development of social and environmental links in development strategies for Cameroon.

\section{Research Methodology}

Since the linkage between the social and environmental pillars are particularly under-researched (Murphy, 2012), we used an exploratory research approach. This implies that the research is designed to come up with final answers but intended to investigate an area that has been underresearched (Nagy et al., 2011). The overall exploratory research strategy includes: a literature review and development of a check-list of questions (Step 1); Unstructured interviews with a relatively small group of people, and these people are almost never randomly selected to participate (Step 2).

Step 1: Analysis according to checklist

We reviewed existing checklists, relevant literature on social sustainability, social and environmental links and environmental sustainability. Then we extracted the items, grouped them under five conceptual categories to develop a checklist consisting of 33 questions.

Furthermore, to complete an acceptable version of the checklist, we used a pilot test of the critical feedback and an expert panel with diverse backgrounds as a means to assure reliability and validity of a checklist design (Yin, 2009; Fink, 2003).

The final five categories are:

\section{Commitment to Social and Environmental Links (Eight Questions)}

This assessed whether these strategies reflected the thrust of relevant national, regional and international goals and agreements promoting social and environmental links. It also assessed if these strategies acknowledged sustainable development. Questions for this category were informed by the work of Turcu (2013); Ngouana and Tchoffo (2011); MINEPDED (2010) and Hugé and Hens (2007).

\section{Equity (Seven Questions)}

This attempted to assess how the concept of equity was linked to environmental imperatives and what policy implications emerged from these synergies. Questions focused on vulnerable groups, land grabbing, etc. The concept of vulnerable groups is open to interpretation (Larkin, 2009) but in this paper vulnerable groups refer to those persons who are underprivileged because of their social position, marginalization, poor mental and 
physical health, low income or other factors (MINEPAT, 2013). Questions for this category were extracted and adapted from Murphy (2012); Bele et al. (2011) and Alessa et al. (2009). In this paper, equity refers to a wide spectrum of policy areas ranging from the provision of clean water, nutrition, etc. and an unpolluted environment and access to social networks (Murphy (2012).

Awareness for Sustainability (Five Questions)

Awareness for sustainability is a key social concept in Sustainable Development discourse (Murphy, 2012). This category was informed by Murphy (2012), Franks et al. (2014), Davis and Franks (2014) and, Ngouana and Tchoffo (2011).

\section{Participation (Seven Questions)}

Questions assessed the extent to which desires, views and preferences of vulnerable groups, including future generations, are reflected in the strategies analyzed. Ideas for this category were extracted from Murphy (2012), Esteves et al. (2012), Hugé et al. (2011) and, Ngouana and Tchoffo (2011).

\section{Social cohesion (Six questions)}

This assessed whether the strategies show commitment to developing initiatives that combat the kinds of environmental conditions that promote social disharmony or upheaval. This category was guided by the works of Murphy (2012), Keitumetse (2014), Cuthill (2009), Owen and Kemp (2014).

Part of the checklist is presented in Table 3 for illustrative purposes.

\section{Equity (07 questions)}

1. Does the strategy include commitment to assist vulnerable groups coping with the effects of large infrastructure projects?

2. Does the strategy show commitment to guide vulnerable groups to diversified enterprises evolving due to infrastructure projects?
3. Does the strategy show commitment to dedicate/capture revenues from the exploitation of natural resources to/for local social development priority areas?

4. Does the strategy include commitment to avoid appropriation of productive resources such as land, medicinal plants, etc. by the rich /multinational and powerful?

5. Does the strategy show commitment to address/minimize the environmental effects of vulnerable groups?

6. Does the strategy show commitment to assist vulnerable groups adapting to the effects of extreme environmental degradation and climate-induced changes?

7. Does the strategy show commitment to protect vulnerable groups from the adverse impacts of fiscal policies designed to protect environment?

The checklist has been applied to one national development strategy (GESP, 2009), three sectoral development strategies (Social Services Sectoral Development Strategy (2014-2020); Health sector strategy 2009-2015; Industry and Services Sector Development Strategy and action plans, 2008) and two sub-sectoral development strategies (Livestock, Fisheries and Animal Husbandry (MINEPIA) Sub-sector strategy, 2012; Environment, Protection of Nature and Sustainable Development (MINEPDED) sub-sector strategy, 2012).

In checklist approaches, assessment is done qualitatively (Olsen and Fenhann, 2008) and quality is best measured on an ordinal scale (Batschelet, 1979). Answers to the questions are scored on a three-point ad hoc ordinal scale (Forrest and Bjorn, 1986), where 1 stands for 'issue not mentioned', 2 for 'issue mentioned but not elaborated' and 3 for 'issue elaborated'. We did not consider a score of 0 because it will not be sensible and will exclude a category from the analysis. 
Each checklist question per category received one of the above scores. These scores referred to the number of questions in each category of questions. This ranking scale has mutually exclusive and exhaustive categories; there is no absolute magnitude of the difference between categories (Altman et al. 1983) but there is order between them, as indicated by expressions such as 'not mentioned', 'not elaborated' or 'elaborated'.

The central tendency descriptive statistical method used in this research is median, which is appropriate for an ordinal scale (Stevens, 1946; Forrest and Bjorn, 1986).

\section{Step 2: Unstructured Interviews}

To enrich documents analysis, unstructured interviews with 21 key stakeholders was held from November
2013 through January 2014. Targeted key informants included those who were involved in the strategy development process and those who were not involved but were better placed to offer credible and valuable perspectives on social and environmental links in Cameroon. For example, the following questions were asked to respondents: how do you think social-environmental links were developed in the strategy formulation process? Were there any debates/discussions on the inclusion of social-environmental links?

\section{Results and Discussion}

Based on checklist categories, Table 5 portrays a selection of key socialenvironmental link issues in the analyzed development strategies.

Table 5: Consideration of selected key social and environmental links in the analyzed strategies

\begin{tabular}{|c|c|c|c|c|c|c|}
\hline $\begin{array}{l}\text { Key social and environmental link } \\
\text { categories }\end{array}$ & 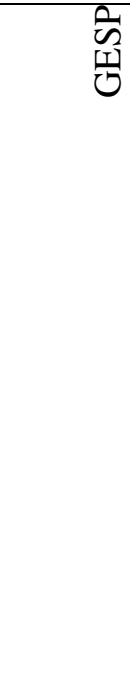 & 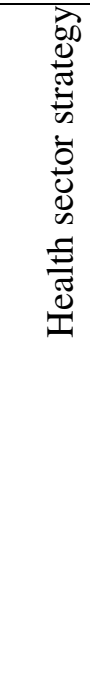 & 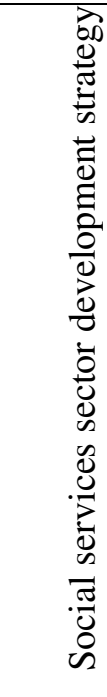 & 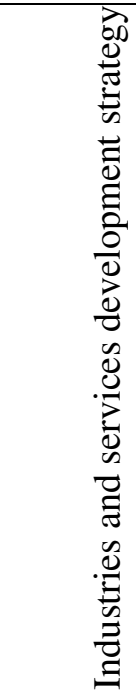 & 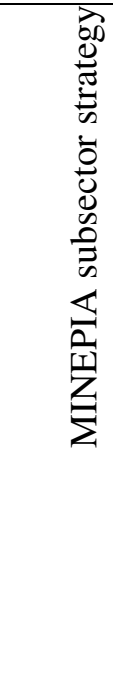 & 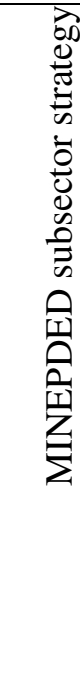 \\
\hline MEDIAN (MD) & MD & $\mathrm{MD}$ & MD & MD & $\mathrm{MD}$ & MD \\
\hline $\begin{array}{l}\text { 1.Commitment to social and environmental } \\
\text { links (08 questions) }\end{array}$ & 3 & 1 & 1 & 1,5 & 1 & 3 \\
\hline 2. Equity (07 questions) & 2 & 1 & 2 & 2 & 2 & 3 \\
\hline $\begin{array}{l}\text { 3- Awareness for Sustainability (05 } \\
\text { questions) }\end{array}$ & 2 & 3 & 3 & 3 & 2 & 3 \\
\hline 4-Stakeholder Participation (07 questions) & 3 & 3 & 2 & 2 & 2 & 2 \\
\hline 5. Social cohesion (06 questions) & 2,5 & 2,5 & 3 & 3 & 2,5 & 3 \\
\hline
\end{tabular}


As ordinal variables allow us to rank the items, we measure them in terms of which has less or more of the quality represented by the variable (Stevens, 1946).

Table 5 shows that commitment to social and environmental links is well considered in the GESP but not in the subsequent sectoral strategies. In general, social and environment are often treated separately and links between them are weak. The exception to this trend is MINEPDED sub-sector strategy which consistently recognized social and environmental linkages. Table 5 also shows that awareness for sustainability and social cohesion are well addressed in most strategies. Except MINEPDED sub-sector strategy, emphasis on equity is lacking in most of the strategies. Stakeholder participation is less considered in four strategies analyzed. Table 5 suggests disconnect between various levels of planning.

The next section discusses the qualitative appreciation of some selected aspects within checklist categories in the light of interview results.

Commitment to Social and Environmental Links

Sustainable development is mentioned in the majority of the strategies analyzed. MINEPDED sub-sector strategy reflects on the complex interdependencies between economic, social and environmental phenomena but does not operationalize sustainability in the Cameroonian context. This lack of operationalization opens ground for more contention because no single way of telling the extent to which sustainability is achieved has been agreed so far (Turcu, 2013; Mustafa and AbdulRazak, 2011). Documents analyzed portray a mechanistic breakdown of sustainability into its parts. The breaking down of sustainability to the various components cannot enable planners to capture social and environmental links.

References to agreements promoting social and environmental links vary from one strategy to another. They are not mentioned in the health sector strategy, and in the Livestock, Fisheries and Animal Husbandry (MINEPIA) sub-sector strategy. The GESP makes references to Indigenous and Tribal Peoples, environment-health nexus, and Waste Management for Human Health and Livelihood, whereas the MINEPDED sub-sector strategy and the Industries and Services sector strategy respectively elaborates on green economy and Corporate Social Responsibility (CSR). Green economy and CSR are likely to foster social and environmental links (UNEP, 2011; UNEP, 2013; GIZ, 2013), if appropriate enabling actions (resources are mobilized, awareness, incentives, regulations, compliance and enforcement measures) are undertaken.

\section{Equity}

The health sector strategy shows commitment to address occupational health and safety but it insufficiently considered commitment to assist vulnerable groups coping with the effects of large infrastructure projects. These projects are subjected to Environmental and Social Impact Assessment and their social and environmental impacts are well considered in the MINEPDED sub-sector strategy. The failure to consider health impacts of large infrastructure projects in a health sector strategy while many large projects are underway, could lead to major shortfalls. For example, the lack of health baseline data and an incomplete assessment makes it difficult to address long-term issues of global community health in the ChadCameroon pipeline project (Harisson and Coussens, 2007).

The MINEPDED sub-sector strategy shows commitment to develop an Access 
and Benefit-Sharing (ASB) policy but the Health sector strategy also fails to show its contribution towards avoiding appropriation of productive resources such as medicinal plants by the rich /multinational and powerful, this failure could spur the inequity currently being faced by African communities. Multinational pharmaceutical and biotechnological companies have created profitable private monopolies over Africa's genes, plants and related traditional knowledge (Oyewunmi, 2013), and biopiracy is widespread in Africa (Heong, 2006).

The strategies assessed are committed to dealing with hazard risks that may derail or constrain their goals. This is important because human-induced hazard could dangerously increase inequality. The strategies are also committed to addressing the environmental impacts on vulnerable groups but they do not consider refugees environmental impacts.

Social Services and, Industries and Services strategies show commitment to guide vulnerable groups to diversified enterprises evolving due to the exploitation of natural resource and infrastructure projects. In as much as these strategies pay attention to social safety nets, other strategies assessed lack a comprehensive view on guiding vulnerable groups to diversified enterprises evolving due to infrastructure projects and the exploitation of natural resources. The adverse impacts on vulnerable groups of regulatory policies designed to mitigate climate change or to protect environment are not considered despite their growing importance.

\section{Awareness for Sustainability}

Environmental awareness, capacity building, research and promotion of all forms of information are considered in most of the reviewed strategy documents. Notwithstanding this consideration, according to Civil Society Organizations (CSOs) representatives interviewed education for sustainability is still a challenging issue in Cameroon because many development strategies lack an appropriate communication and awareness strategy. This argument was contested by an interviewee from the Ministry in charge of the environment who revealed that a National environmental educational and awareness program (2014-2018) was developed in September 2013. He further contended that, this program with a budget estimated at 19.990.639 USD for seventeen sectoral ministries and at 25.056.267 USD for municipalities and regional public administrations will surely bridge the gap is appropriate resource is available for its efficient implementation.

\section{Stakeholder Participation}

Strategies analyzed paid attention to participation. Most sectoral and subsectoral strategies present fragments of the planning process and emphasize that consultation and validation workshops were held in various agro-ecology zones. However, the attempts to include the marginalized groups in the policy discussion lacked credibility. None of these strategies provided data on the number of participants involved; disaggregated either by ethnicity, sex or socio-professional categories. This weakness is in line with findings of Hughes (2005) who underscored a limited fulfillment of minorities' and indigenous peoples' rights in development policy processes. In the term of national and sectoral ownership of these strategies, interviewees feel frustrated. Main reasons for this are that the approach confuses consultation for involvement, and there has been no opportunity for debating alternatives development pathways. Furthermore, insights from local Government institutions are not always captured and most funding 
concentrated at the central level of the ministries.

Monitoring and Evaluation system, and inter-sectoral co-operation are well elaborated in the strategies analyzed. Notwithstanding this thoroughness, according to CSOs, in Cameroon intersectoral cooperation remains a permanent challenge because of poor governance. This lack of coordination between national institutions in Cameroon is also acknowledged by other authors (Ngouana and Tchoffo 2011; Greiber and Schiele 2011). Lack of coordination always results in conflict and wasted resources (Partidário et al. 2008). Pathways to social and environmental linkages require a multistakeholder engagement, coordinated system and a systemic change.

There is a clear commitment to information sharing, generation and use of data, but according to public institution representatives and academics interviewed, Cameroon lacks an operational database for monitoring the social and environmental links which are still in early stages of research. In addition, social services sector strategy underscores the lack of a Social Information System (SIS).

\section{Social Cohesion}

Issues of equitable access to/and control over natural resources for women and men, commitments to combating the kinds of environmental conditions that cause civic strife and commitments to infrastructure planning that concurrently promotes social integration and environmental sustainability simultaneously are usually considered adequately, while the promotion of social activities aimed at environmental goals is poorly considered in the MINEPDED subsector strategy. For example, one strategy plans to increase the rate of access to sanitation infrastructure from 15 to more than 60 per cent at the end of 2020. Decent employment opportunities are mentioned in most strategies analyzed. However, they do not operationalize decent employment in the Cameroonian context. They also lack a comprehensive view of decent employment with regards to wages, career prospects, job quality and security.

The industries and services strategy plans to encourage private sector investments in local infrastructures, MINEPDED sub-sector strategy plans to promote ASB, however, an explicit commitment to capture revenue and promote redistribution of revenue from the exploitation of natural resource is lacking in the strategies assessed. Benefit sharing as a long-term arrangement can provide equitable development, sustainability and smooth project (Wang, 2012) if local communities properly manage "their share" of revenues (Nodem et al., 2012). Specific attention needs to be paid to redistribution of revenue, and social issues around largescale natural resource extraction projects. Violence and social breakdown can be the most severe constraint to sustainability (Ali, 2014).

\section{Conclusions}

The foregoing section has identified and discussed social and environmental strengths of the strategies and areas where more information and/or action may be needed. Many issues of importance are not well considered: participation of marginalized groups lacks credibility; benefits sharing are hardly mentioned and if so, in extremely general non-binding terms. Evidence has shown that as the first generation PRSPs, the GESP replicates a mechanistic breakdown of sustainability into its parts economy, social and environment. But otherwise, the MINEPDED Subsector Strategy plans to focus on the reconciliation of environment/social and their interactions. As sustainable development, green 
economy and Corporate Social Responsibility are elaborated in few strategies analyzed but there are not much than the "translation" of concepts and standards with little local consultations. Strategies analyzed recognize and deal with inter-sectoral links. Inter-ministerial, intersectoral working groups do exist, but in practice, they seem to be ineffective. Pathways to sustainability require a robust political will (quality of policy implementation), a planning process with room for disagreement, systemic change and attitudes changing at all levels. One limit of this study is that it does not focus on institutions set to achieve social and environmental linkages. In addition, there is a certain level of discomfort using checklist in sustainability assessment process, but the method presented in this paper is intended as a step towards developing greater linkage between the social and environmental pillars in development strategies in developing countries.

\section{References}

Alemagi, D. (2011). Sustainable development in Cameroon's forestry sector: Progress, challenges, and strategies for improvement. African Journal of Environmental Science and Technology Vol. 5(2), pp. 65-72.

Alessa, L., Kliskey, A. and Altaweel, M. (2009). Toward a typology for socialecological systems. Sustainability: Science, Practice, \& Policy. Spring/Summer 2009 | Volume 5 | Issue 1.

Ali, H.S. (2014). Social and Environmental Impact of the Rare Earth Industries. Resources 2014, 3, 123-134. Doi: 10.3390/resources3010123. OPEN ACCESS, available from: www.mdpi.com/journal/resources
Altman, D.G., Gore, S.M., Gardner, M.J. and Pocock, S.J. (1983). Statistical guidelines for contributors to medical journals. British Medical Journal, 286: 1489-1493.

Batschelet, E. (1979). Introduction to Mathematics for Life Scientists. Berlin and New York: SpringerVerlag.

Bele, M., Youssoufa, O.S., Sonwa, D.J., Ndi, N.J. and Locatelli, B. (2011). Forests and climate change adaptation policies in Cameroon. Mitig Adapt Strateg. Glob. Change 16:369-385.

Bojö, J.K.G., Kishore, S., Pilapitiya, S. and Reddy, R.C. (2004). Environment in Poverty Reduction Strategies and Poverty Reduction Support Credits. Environment Department PAPER N ${ }^{\circ}$. 102. World Bank, Washington, D.C.

Cuthill, M. (2009). Strengthening the social in sustainable development: developing a conceptual framework for social sustainability in a rapid urban growth region in Australia. Sustain-able Development 18(6):362373.

Davis, R. and Franks, D.M. (2014). "Costs of Company-Community Conflict in the Extractive Sector." Corporate Social Responsibility Initiative Report No. 66. Cambridge, MA: Harvard Kennedy School. Available from: http://www.hks.harvard.edu/mrcbg/CSRI/research/Costs\%20of\%20 Conflict_Davis\%20\%20Franks.pdf.

Driscoll, R. and Evans, A. (2005). "SecondGeneration Poverty Reduction Strategies: New Opportunities and Emerging Issues". Development Policy Review, 23(1): 5-25.

Esteves, A.M., Franks, D. and Vanclay, F. (2012). Social impact assessment: the state of the art, Impact Assessment and Project Appraisal, 30(1): 35-44. 
Fink, A. (2003). The Survey Handbook, 2nd edition. Thousand Oaks, CA: Sage.

Franks, D.M., Davis, R., Bebbington, J.A., Saleem H.A., Kemp, D. and Scurrah, M. (2014). Conflict translates environmental and social risk into business costs. Sustainability Science vol. 111 No. 21. Available from: http://www.pnas.org/content/111/21/7 576.full.

Forrest, M. and Bjorn, A. (1986). Ordinal scale and statistics in medical research. British Medical Journal, 292, 537.

Gesellschaft für Internationale Zusammenarbeit (GIZ), (2013). Shaping Corporate Social Responsibility in sub-Saharan. Guidance Notes from a Mapping Survey. Bonn: GIZ.

Greiber, T. and Schiele, S. (2011). Governance of Ecosystem Services. Gland, Switzerland: IUCN. Xii + 140 pp.

Gough, I., Meadowcroft, J., Dryzek, J., Gerhards, J., Lengfeld, H., Marandya, A., and Ortiz, R. (2008). JESP symposium: climate change and social policy. Journal of European Social Policy, 18(4):325-344.

Hambira, W.L. (2009). Poverty reduction strategies and the environment: the case of Botswana. 'IAIA09 Conference Proceedings', Impact Assessment and Human Well-Being 29th Annual Conference of the International Association for Impact Assessment, 16-22 May 2009, Accra International Conference Center. Ghana: Accra. Available from: http://www.iaia.org/iaia09ghana/docu ments/cs/CS64_Hambira_Poverty_Re duction_Strategies.pdf.
Harms, R. (1999).Games against nature an eco-cultural history of the Nunu of Equatorial Africa. Cambridge (MA).

Harisson, M. and Coussens, C. (2007). Global Environmental Health in the 21st Century: From Governmental Regulation to Corporate Social Responsibility. Washington, DC: National Academies Press. Available from:

http://www.nap.edu/catalog.php?recor d_id $=11833$.

Heong, C.Y. (2006). New report points to widespread biopiracy in Africa. THIRD WORLD RESURGENCE \#186. Available from: http://www.twnside.org.sg/title2/twr1 86.htm.

Hugé, J. and Hens, L. (2009). The greening of poverty reduction strategy papers: a process approach to sustainability assessment, Impact Assessment and Project Appraisal, 27:1, 7-18.

Hugé, J., Waas T., Eggermont, G. and Verbruggen, A. (2011). Impact assessment for a sustainable energy future-Reflections and practical experiences. Energy Policy, 39: 6243-6253.

Hughes, A. (2005). PRSPs, Minorities and Indigenous Peoples - An Issues Paper. Minority Rights Group International- London, MRG.

International Monetary Fund (IMF), (2010). Country Report No. 10/257 Cameroon: Poverty Reduction Strategy Paper. IMF, Washington, D.C. Available from: http://www.imf.org/external/pubs/ft/s cr/2010/cr10257.pdf.

Keitumetse, S.O. (2014). Cultural Resources as Sustainability Enablers: Towards a Community-Based Cultural Heritage Resources Management (COBACHREM) Model. Sustainability, 6(1):70-85. 
Available

from:

http://www.mdpi.com/20711050/6/1/70.

Larkin, M. (2009). Vulnerable groups in Health and Social Care. Sage Publications.

Littig, B. and Griessler, E. (2005). Social sustainability: a catchword between political pragmatism and social theory. International Journal of Sustainable Development, 8(1-2):6579.

Murphy, K. (2012). The social pillar of sustainable development: a literature review and framework for policy analysis. Sustainability: Science, Practice, \& Policy. Winter 2012 । Volume 8 । Issue 1. Available from: http://sspp.proquest.com/static_conte nt/vol8iss1/1008-041.murphy.pdf.

Ministry of the Economy, Planning and Regional Development (MINEPAT), (2013). Stratégie sectorielle de développement des services sociaux : état des lieux et diagnostic. 161p. MINEPAT, Yaoundé (Cameroun).

Ministère de l'Environnement, de la Protection de la Nature et du Développement Durable (MINEPDED), (2010). Rapport de l'analyse situationnelle et estimation des besoins dans le domaine de santé en environnement au Cameroun. 184p. Yaounde (Cameroon): MINEPDED. Available from: www.afro.who.int/fr/downloads/doc download/5791-cameroon.html.

Ministry of the Economy, Planning and Regional Development (MINEPAT), (2011). Guide méthodologique de planification stratégique au Cameroun. MENEPAT, Yaoundé(Cameroon). Available from: http://minepat.gov.cm/dgpat/index.ph p/planification/outils-de- planification/guide-de-planificationstrategique

Mustafa, D. and Abdul-Razak, N.A. (2011). Islamic Development Bank (IDB), Foreign Aid and the Challenges for Sustainable Development in Africa. International Journal of Business and Social Science Vol. 2 No. 4.

Nagy, S., Hesse-Biber, S. and Leavy, P. (2011). The Practice of Qualitative Research. Second Edition SAGE Publications, Inc.

Ngouana Kengne, C. V. and Tchoffo, B. (2011). The sustainability assessment of the National Aquaculture Strategy for Cameroon. Impact Assessment and Project Appraisal, 29(2): 141150.

Nodem, V., Bamenjo, J.N. and Schwartz, B. (2012). subnational natural resource revenue management in Cameroon. Forest and Mining Royalities in Yokadouma, East Cameroun. RELUFA: Yaounde. Available from :http://www.relufa.org/documents/sub nationalrevenuestudy.pdf.

Turcu, C. (2013). Re-thinking sustainability indicators: local perspectives of urban sustainability. Journal of Environmental Planning and Management, 56(5): 695-719.

The United Nations Environment Programme (UNEP), (2011). Towards a Green Economy: Pathways to Sustainable Development and Poverty Eradication. Nairobi: UNEP. Available from: http://www.unep.org/greeneconomy/ GreenEconomyReport.

The United Nations Environment Programme (UNEP), (2013). Green Economy Scoping Study: South African Green Economy Modeling Report (SAGEM) - Focus on Natural 
Resource Management, Agriculture, Transport and Energy Sectors. Nairobi: UNEP.

Oyewunmi, A.O. (2011). Sharpening the Legal Tools to Overcome Biopiracy in Africa Through Pro-development Implementation of Normative International Standards: Lessons from Brazil, South Africa and India. African Journal of International and Comparative Law, 21: 447-466.

Olsen, K.H. and Fenhann, J. (2008). Sustainable development benefits of clean development mechanism projects. A new methodology for sustainability assessment based on text analysis of the project design documents submitted for validation. Energy Policy, 36: 2819-2830.

Owen, J.R. and Kemp, D. (2014). 'Free prior and informed consent', social complexity and the mining industry: Establishing a knowledge base. Resources Policy; Volume 41, Pages 91-100.

Partidário, M.R., Paddon, M., Eggenberger, M., Minh Chau, D. and Nguyen V.D. (2008). Linking strategic environmental assessment (SEA) and city development strategy in Vietnam. Impact Assessment and Project Appraisal, 26(3): 219-227.
Republic of Cameroon, (2009). Growth and employment strategy paper 2010/2020. Available from: http://www.imf.org/external/pubs/ft/s cr/2010/cr10257.pdf.

Stevens, S.S. (1946). On the theory of scales of measurement. Science, New Series, 103(2684) 677-680.

Volkery, A., Klaus, J., Bregha, F., Pintér, L. and Swanson, D. (2004). Coordination, Challenges and Innovations in National Sustainable Development Strategies-Based on a 19-Country Analysis. Paper presented at the 2004 Berlin Conference on the Human Dimension of Global Environmental Change "Greening of Policies: Inter-linkages and Policy Integration". Panel B3 "National Policy Integration 2". Berlin: Germany.

Wang, C. (2012). A guide for local benefit sharing in hydropower projects. Social development papers ; no. 128. Social sustainability and safeguard. Washington, DC: World Bank. Available from: http://documents.worldbank.org/curat ed/en/2012/06/16465910/guide-localbenefit-sharing-hydropower-projects.

Yin, R.K. (2009). Case Study Research: Design and Methods, 4th edition. Thousand Oaks, CA: Sage. 